\title{
POLITENESS IN USING PAKPAKNESE IN PERSONAL SUBJECT PRONOUNS IN DAILY CONVERSATION AT JAMBU MBELLANG
}

\author{
Pricilia \\ Sri Minda Murni \\ Sisila Fitriany Damanik \\ Universitas Negeri Medan
}

\begin{abstract}
This descriptive qualitative research deals with the Politeness in Using Pakpaknese in Personal Subject Pronouns in Daily Conversation at Jambu Mbellang. The problem of the study were to find the (1)types of politeness in using Pakpaknese in personal subject pronouns show daily conversation, (2)how to personal subject pronouns show daily conversation and (3)why Pakpak people need to show personal subject pronoun by Pakpaknese. The data were collected by taken 30 people (15 male and 15 female) at Jambu Mbellang District as respondent/participant were collected by using questionnaire, recording the daily conversation of Pakpaknese people,the last data the researcher used interview and then were transcribed. The data were analyzed by qualitative research based on Brown and Levinson. The result of the research shown that second types of politeness show pakpaknese, how do Pakpak people show personal subject pronouns and why Pakpak people need show personal subject pronouns. The analyzed of questionnaire that speaker male speak to male the equal language were often used and in the speaker male speak female the younger language were often used. In the speaker of female speak female show younger language to used communication and female speak male the older language were often used. types of politeness in show PSP, on record the answer how Pakpak people show PSP that conversation found four speech function, and used interview found intimacy, politeness, relation, adapting situation into ever conversation in Pakpak why Pakpak people need to show PSP.
\end{abstract}

Keywords : pakpaknese, personal pronouns, politeness,

\section{INTRODUCTION}

Human need other human in their life. Communication is the way how human can interact each other. When people talk they do not only exchange information but also form certain interpersonal relationship. Politeness, as well as social language is very important to values the characteristic and someone personality. George Yule (2005:60) explain politeness is an interaction, can then be defined as the means employed to show awareness of other person's face. People who have good attitude are those who can accept and appreciate other cultures and languages without forgetting their origin. This can be good value in the presence of other people or countries when knowing the local language in Indonesia can't be extinct or lost because there are still many speakers who care to use.

One aspect to measure the politeness of language is using of pronouns. Local languages such as Pakpak language have pronouns. This serves to avoid misunderstanding due to mis-use of pronouns that are inconsistent with the etiquette and polite manners of the speakers. Pronouns in local language such as Pakpak language are more than the prescribed Indonesian standard; it depends on the area of show and response received by the other person. The conversation types of personal pronouns here are the most use in conversation and as the depiction of phenomena that occur in daily life of Pakpaknese at Jambu Mbellang District:

$$
\begin{aligned}
& \text { Ko 'kamu' (You) } \\
& \text { Kono 'kamu' (You) }
\end{aligned}
$$




\title{
Ke 'kalian' (You)
}

Kene 'kalian' (You)

The use of ko politeness is used when talking to a parent or someone above our age and adding a nickname, (marga, gelar) in front after ko. Beside the use of the word Ko in equal or standard is used when the Ko is used among each other or the same age us, while use impoliteness when the used of ko is talking to a parents or someone above our age without adding the word in front after ko. Usually between son and mother, students and lecturer.

\author{
Example Conversation 1 : Son \&Daddy(politeness) \\ Son: ko bapak, ngoh mangan? \\ Daddy : olo mang, parjolo ma! \\ Conversation 2: brother \& Sister (equal) \\ Sakkap :ko, ngoh mangan? \\ Lia : ngoh makan aku. \\ Conversation 3: daughter \& mother (impolite) \\ Daughter :ko ,ngoh mangan? \\ Mother : sip mo ko!
}

The show of pronouns in the Pakpak language mixed with sentences in Bahasa Indonesia does not impact politeness level of a speaker speak directed to other speaker, but instead a speaker is considered unaware of custom and ethics in social life if the use of pronouns is misdirected. This is what often found in the middle of conversations of people at Jambu Mbellang district from that Criteria Politeness show Pakpaknese personal subject pronouns in the society is very important. The researcher believes that not all people can use politeness personal pronouns in right way when they don't know some parameters of speaker or interlocutor. To make sure pronouns directed to the appropriate interlocutor some parameters such as Gender, Age, Situation, and familiarity are very influential in this regard. Therefore, the researcher wants to know whether or not Pakpaknese personal subject pronouns influenced level of politeness, researcher interested in conducting a research which focuses on analyzing Politeness in using Pakpaknese in Personal Subject Pronouns in Daily Conversation at Jambu Mbellang district.

This part reviews some theoretical backgrounds related to the personal subject pronoun in Pakpaknese. Furthermore, the politeness of the pronouns is also presented briefly.

\section{Politeness}

While Brown \& Levinson (1978: 67) provide a slightly different perspective on politeness phenomena, they assume that all competent adult members of a society know each other to have "face", which they characterize as "public self-image that every member wants to claim for himself" and politeness is seen as trade in this commodity. Face consists of the freedom to act unimpeded (negative face) and the satisfaction of having one's values approved of (positive face). Politeness as adherence to Politeness Maxims, Lakoff (1973) suggested that three 'rules of rapport' underlie the choice of linguistic expression, rules which can account for how speakers deviate from directly expressing meanings. 
According to Mills (2003:74) "politeness can be seen to have a wide range of meanings, both for theorists and interact, and can be show to describe third politeness criteria older, younger, and Equal a very diverse set of behavior". Yule (2005:61), distinguished negative and positive face, Face is interaction are not living in a context which has created rigidly fixed social relationships. Every day social interactions, people generally behave as if their expectations concerning their public self-image, or their face. Negative face is the need to be independent, to have freedom of action, and not to be imposed on by others. While Positive face is the need to be accepted, even liked, by others to be treated as a member of the same group, and to know that is or her wants are share by others. In simple terms, negative face is the need to be independent and positive face is the need to be connected.

\section{Personal Pronouns}

Personal Pronouns are the pronouns used to refer to people. The personal pronouns may refer to the self (first personal pronouns), referring to the person to be spoken to (the second personal pronouns) or referring to the person in question (third personal pronouns). Among the pronouns, some refer to the one or more than one.

\section{Personal Pronouns in Pakpaknese}

There are different variants of the politeness level for pronouns, and this level determined by definition of each pronoun according to Kamus Pakpak-Indonesia, and it is showed below.

Table 1. Types of Personal Subject Pronouns in Simalungunese

\begin{tabular}{|c|c|c|c|c|c|c|}
\hline \multirow{2}{*}{$\begin{array}{l}\text { Level of } \\
\text { politeness }\end{array}$} & \multicolumn{2}{|l|}{$\begin{array}{l}\text { First } \\
\text { PSP }\end{array}$} & \multicolumn{2}{|c|}{$\begin{array}{l}\text { Second } \\
\text { PSP }\end{array}$} & \multicolumn{2}{|c|}{$\begin{array}{l}\text { Third } \\
\text { PSP }\end{array}$} \\
\hline & $\begin{array}{l}\text { SL } \\
\text { (I) }\end{array}$ & $\begin{array}{c}\text { PL } \\
(\mathrm{We})\end{array}$ & $\begin{array}{c}\text { SL } \\
\text { (You) }\end{array}$ & $\begin{array}{c}\text { PL } \\
\text { (You) }\end{array}$ & $\begin{array}{c}\text { SL } \\
\text { (He/She,It) }\end{array}$ & $\begin{array}{c}\text { PL } \\
\text { (They) }\end{array}$ \\
\hline I(politeness) & Aku/au & Kami & Kono & Kene & Turang & Khalaki \\
\hline \multirow[t]{2}{*}{ II (neutral) } & \multirow[t]{2}{*}{$\mathrm{Aku} / \mathrm{au}$} & \multirow[t]{2}{*}{ Kami } & Ko & \multirow[t]{2}{*}{$\mathrm{Ke}$} & \multirow[t]{2}{*}{ Impal } & \multirow{2}{*}{$\begin{array}{c}\text { Khalak } \\
\text { ke }\end{array}$} \\
\hline & & & Kam & & & \\
\hline III ( Rude) & $\begin{array}{c}\text { Sebut nama } \\
\text { sendiri }\end{array}$ & Kita & Oe & $\begin{array}{c}\text { Sebut nama } \\
\text { sendiri }\end{array}$ & Silih & $\begin{array}{c}\text { Khalak } \\
\text { en }\end{array}$ \\
\hline
\end{tabular}

From the table above, it can be seen that singular first person pronouns have two variants - Aku (I) and sometimes mention the speaker's name for example Lia (I). Mention speaker's name in the middle of conversation to the hearer belongs to the third level that is rude or impolite because it's considered to be arrogant. For the plural first person pronouns variant only one it is kami.

In terms of singular second personal pronouns, there are six variants that separated in to three parts, consider polite are kam and kono, Neutral there are oe and bayo, usually using when we talk with friends in the similar age, but sometimes old man used it to the young man to show closeness and their don't have a limit. ko and impal considered to be rude because people use both of them when start to get angry and uncomfortable feeling, also to make sure something like what speaker think before. For the plural second pronouns, there are three variants kene, kam and mention one by one hearer/ interlocutor's name for example nino, nina (You). This is considered rude or 
impolite because it impressed that the speaker had just found out who are the name of the other person and also show unfamiliarity.

In terms of singular third personal pronouns, there are five variants they are Impal, dedahen, turang, silih, anggi + hearer's name. turang(she) and silih(he) are considered rude and impolite because it indicates that the speaker do not know or forget who the other person's name is, sometimes considered that the speaker and the listener have bad relationship. For plural third personal pronouns, just 2 variants they are mike and khalaknai. mike is the only pronoun who are considered polite and usually used in everyday life, that refers to a group of people whereas khalaknai like the meaning of 'that people' is considered rude because it seems like speaker do not know who a bunch of people there around her/him.

\section{RESEARCH METHODOLOGY}

This study was descriptive qualitative design that taken 30 people ( 15 Male \& 15 Female) of Jambu Mbellang Distric as respondent/participant. The data was collected by using questionnaire paper that consists of 25 questions, record and interview it is about Pakpaknese in Personal Subject Pronouns respondent/participant to show daily conversation Pakpak language.

\section{Data Analysis}

Table 2. Types of Politeness Show Pakpaknese in Personal Subject Pronouns in Daily Conversation

\begin{tabular}{|c|c|c|c|c|c|c|c|}
\hline Gender & No & \multicolumn{3}{|c|}{ Male } & \multicolumn{3}{|c|}{ Female } \\
\hline \multirow{8}{*}{ Male } & & $\begin{array}{l}\text { Younger } \\
\text { (baik) }\end{array}$ & $\begin{array}{l}\text { Equal } \\
\text { (standar) }\end{array}$ & $\begin{array}{l}\text { Older } \\
\text { (sopan) }\end{array}$ & $\begin{array}{l}\text { Younger } \\
\text { (baik) }\end{array}$ & $\begin{array}{l}\text { Equal } \\
\text { (standard) }\end{array}$ & $\begin{array}{l}\text { Older } \\
\text { (sopan) }\end{array}$ \\
\hline & 1 & - & $\begin{array}{l}\text { Dahari ko } \\
\text { mulak. }\end{array}$ & - & $\begin{array}{l}\text { Dahari ko } \\
\text { mulak } \\
\text { pa/beru }\end{array}$ & & \\
\hline & 2 & - & - & $\begin{array}{l}\text { Naing mike } \\
\text { ko laos pak }\end{array}$ & $\begin{array}{l}\text { Beru kade } \\
\text { ko } \\
\text { dedahen }\end{array}$ & - & - \\
\hline & 3 & $\begin{array}{l}\text { Marsakit } \\
\text { ko dek }\end{array}$ & - & - & $\begin{array}{l}\text { Kasa } \\
\text { bagak ko } \\
\text { dedahen }\end{array}$ & - & - \\
\hline & 4 & - & $\begin{array}{l}\text { Idike itokor } \\
\text { ko baju i }\end{array}$ & - & - & - & $\begin{array}{l}\text { Metasak } \\
\text { kade ko ma }\end{array}$ \\
\hline & 5 & & - & $\begin{array}{l}\text { Sentabi } \\
\text { pertua nami } \\
\text { I dike I } \\
\text { betoh ke } \\
\text { sopo pricil }\end{array}$ & - & - & $\begin{array}{l}\text { Mi onan ko } \\
\text { deket } \\
\text { Namberru }\end{array}$ \\
\hline & No & Younger & Equal & Older & Younger & Equal & Older \\
\hline & 6 & - & $\begin{array}{l}\text { Saut ko } \\
\text { mulak hari } \\
\text { senen i }\end{array}$ & - & - & $\begin{array}{l}\text { Kade naing I } \\
\text { tokor ko }\end{array}$ & - \\
\hline
\end{tabular}




\begin{tabular}{|c|c|c|c|c|c|c|}
\hline 7 & $\begin{array}{l}\text { Naing } \\
\text { mike ko } \\
\text { dedahen }\end{array}$ & - & - & $\begin{array}{l}\text { Enggoh } \\
\text { ko } \\
\text { mangan } \\
\text { Turang }\end{array}$ & - & -- \\
\hline 8 & - & $\begin{array}{l}\text { Pentabi } \\
\text { dedahen } \\
\text { idike I } \\
\text { betehko } \\
\text { BRI }\end{array}$ & - & - & $\begin{array}{l}\text { Pentabidedahen } \\
\text { idike I betehko } \\
\text { BRI }\end{array}$ & -- \\
\hline 9 & - & $\begin{array}{l}\text { I dike ko } \\
\text { tading }\end{array}$ & - & $\begin{array}{l}\text { I dike ko } \\
\text { tading dek }\end{array}$ & - & - \\
\hline 10 & - & $\begin{array}{l}\text { Tolong le } \\
\text { ko taruhkan } \\
\text { aku mulak }\end{array}$ & - & $\begin{array}{l}\text { Jam piga } \\
\text { ko laus } \\
\text { sikola dek }\end{array}$ & - & - \\
\hline 11 & $\begin{array}{l}\text { Naing mi } \\
\text { kampus } \\
\text { ko }\end{array}$ & - & - & $\begin{array}{l}\text { Piga kalak } \\
\text { ke } \\
\text { sebeltek }\end{array}$ & - & - \\
\hline 12 & - & $\begin{array}{l}\text { Naing mike } \\
\text { ko silih }\end{array}$ & - & - & $\begin{array}{l}\text { Naing markade } \\
\text { ko kak }\end{array}$ & - \\
\hline No & Younger & Equal & Older & Younger & Equal & Older \\
\hline 13 & $\begin{array}{l}\text { Pinjam le } \\
\text { carger mu } \\
\text { lot }\end{array}$ & - & - & $\begin{array}{l}\text { Pinjam le } \\
\text { carger mu } \\
\text { lot }\end{array}$ & - & $\begin{array}{l}\text { I dike } \\
\text { sopomu } \\
\text { pung }\end{array}$ \\
\hline 14 & $\begin{array}{l}\text { Baking le } \\
\text { kopi ko }\end{array}$ & - & - & $\begin{array}{l}\text { Baking } \\
\text { kopi ku de }\end{array}$ & - & - \\
\hline 15 & - & $\begin{array}{l}\text { Lot kepeng } \\
\text { mu I isi }\end{array}$ & $\begin{array}{l}\text { I sapo } \\
\text { empung mu }\end{array}$ & - & $\begin{array}{l}\text { Naing menokor } \\
\text { kade ko }\end{array}$ & - \\
\hline
\end{tabular}

Table 3. The Result of Types of Politeness Using Pakpaknese in Personal Subject Pronouns in

\begin{tabular}{|c|c|c|c|c|c|c|c|}
\hline \multicolumn{8}{|c|}{ Daily Conversation } \\
\hline Gender & No & \multicolumn{3}{|c|}{ Female } & \multicolumn{3}{|c|}{ Male } \\
\hline \multirow{5}{*}{ Female } & & $\begin{array}{l}\text { Younger } \\
\text { (baik) }\end{array}$ & $\begin{array}{l}\text { Equal } \\
\text { (standar) }\end{array}$ & $\begin{array}{l}\text { Older } \\
\text { (sopan) }\end{array}$ & $\begin{array}{l}\text { Younger } \\
\text { (baik) }\end{array}$ & $\begin{array}{l}\text { Equal } \\
\text { (standart }\end{array}$ & $\begin{array}{l}\text { Older } \\
\text { (sopan) }\end{array}$ \\
\hline & 1 & $\begin{array}{l}\text { Dahari ko } \\
\text { mulak } \\
\text { pa/beru }\end{array}$ & - & - & 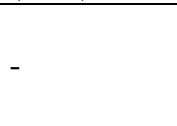 & - & $\begin{array}{l}\text { Naing mike } \\
\text { ko laos pak }\end{array}$ \\
\hline & 2 & $\begin{array}{l}\text { Beru kade } \\
\text { ko } \\
\text { dedahen }\end{array}$ & - & - & - & $\begin{array}{l}\text { Beru kade } \\
\text { ko } \\
\text { dedahen }\end{array}$ & - \\
\hline & 3 & $\begin{array}{l}\text { Kasa } \\
\text { bagak ko } \\
\text { dadahen }\end{array}$ & & & $\begin{array}{l}\text { Marsakit ko } \\
\text { dek }\end{array}$ & & \\
\hline & 4 & & & $\begin{array}{l}\text { Metasak } \\
\text { kade ko } \\
\text { mak }\end{array}$ & & $\begin{array}{l}\text { Idike } \\
\text { itokor ko } \\
\text { baju i }\end{array}$ & \\
\hline
\end{tabular}




\begin{tabular}{|c|c|c|c|c|c|c|c|}
\hline & 5 & 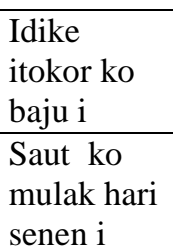 & & & & & $\begin{array}{l}\text { Sentabi } \\
\text { pertua namo } \\
\text { I dike I betoh } \\
\text { ke sopo } \\
\text { pricil }\end{array}$ \\
\hline Female & 6 & Younger & Equal & $\begin{array}{l}\text { Older } \\
\text { Mi onan ko } \\
\text { deket } \\
\text { Namberru } \\
\end{array}$ & $\begin{array}{l}\text { Younger } \\
\text { Kade naing I } \\
\text { tokor ko } \\
\text { bang } \\
\end{array}$ & Equal & Older \\
\hline \multirow{9}{*}{ Female } & 7 & $\begin{array}{l}\text { Jadi ko } \\
\text { mulak hari } \\
\text { senen }\end{array}$ & & & & & $\begin{array}{l}\text { I sapo } \\
\text { empung mu }\end{array}$ \\
\hline & 8 & $\begin{array}{l}\text { Kade } \\
\text { naing I } \\
\text { tokor ko }\end{array}$ & & & & & $\begin{array}{l}\text { Enggo ko } \\
\text { mangan } \\
\text { turang }\end{array}$ \\
\hline & 9 & $\begin{array}{l}\text { I dike I } \\
\text { bakin ko } \\
\text { hepeng i }\end{array}$ & & & & & $\begin{array}{l}\text { Enggo ko } \\
\text { mangan pak }\end{array}$ \\
\hline & 10 & $\begin{array}{l}\text { Naing } \\
\text { mike ko } \\
\text { dedahen }\end{array}$ & & & $\begin{array}{l}\text { Pentabi } \\
\text { dedahen I } \\
\text { dike ibeteh } \\
\text { ko BRI I } \\
\text { kuta en }\end{array}$ & & \\
\hline & 11 & & $\begin{array}{l}\text { Idike ko } \\
\text { tading }\end{array}$ & & & & $\begin{array}{l}\text { I dike } \\
\text { sopomu } \\
\text { mpung }\end{array}$ \\
\hline & 12 & $\begin{array}{l}\text { Jam piga } \\
\text { ko laos } \\
\text { sikolla dek }\end{array}$ & & & & & $\begin{array}{l}\text { Tolong le ko } \\
\text { taruhkan aku } \\
\text { mulak bang }\end{array}$ \\
\hline & 13 & & $\begin{array}{l}\text { Naing } \\
\text { merkade } \\
\text { ko }\end{array}$ & & & $\begin{array}{l}\text { Naing mi } \\
\text { kampus } \\
\text { ko ron }\end{array}$ & \\
\hline & 14 & & $\begin{array}{l}\text { Naing } \\
\text { mike ko } \\
\text { eda }\end{array}$ & & & & $\begin{array}{l}\text { Piga kalak ke } \\
\text { sebeltek }\end{array}$ \\
\hline & 15 & $\begin{array}{l}\text { Jam piga } \\
\text { ko laos } \\
\text { sikolla dek }\end{array}$ & & & & $\begin{array}{l}\text { Lot ku } \\
\text { pinjam } \\
\text { carger ko }\end{array}$ & \\
\hline
\end{tabular}

Table 4. Descriptions How Do People in Jambu Mbellang District Show Pakpanese Personal Subject Pronouns Daily Conversation

\begin{tabular}{|l|l|}
\hline $\begin{array}{c}\text { How do people show } \\
\text { PSP }\end{array}$ & Meaning \\
\hline Suggestion & The action of suggestion something \\
\hline
\end{tabular}




\begin{tabular}{|l|l|}
\hline Command & Give an authoritative order \\
\hline Offer & $\begin{array}{l}\text { Ask someone if they would like to have something or if they would like } \\
\text { you to do something. }\end{array}$ \\
\hline Interrogative Statement & $\begin{array}{l}\text { An interrogative sentence asks a statement, and it always ends with a } \\
\text { question mark. }\end{array}$ \\
\hline
\end{tabular}

From the language it is found how people show politeness in Personal Subject Pronouns realized. The native speaker of people Pakpak used personal subject pronouns when they are communicate to each other

1. " dahari ko mulak nak"( when will you go home)

2. " naing mike ko laos pak (where will you go sir)

3. "I dike I tokor ko baju mi"(where do you buy clothes)

4. "sakit kade ko"(are you sick)

5. "naing markade ko" (what are you doing)

From the data no 1,2,3,4 and 5 above, it is found that when the speaker ask to other, the speaker used 'ko' as Personal subject pronouns by using interrogative statement.

6. "mi onan ko dekket namberru" (will you go the market with aunty)

In the exsample of data no 6 the form is interrogative sentence but the meaning of the sentence is to suggest someone to do something. For there more, the personal subject pronouns of 'ko' can be seen in the type of suggestion.

7. "saut ko mulak hari senen" (will you go home on Monday)

8. "enggoh ko mangan pak" (have you eaten yet,sir)

9. "kade naing I tokkor ko"(what do you want to buy)

From the data represented above 7-9, it is found when speaker speak to other people used offer after personal subject pronouns by interrogative sentence

10. " boi I buat ko gelas I" (can you take the glass)

11. "lot ku pinjam le carger mu" (may I borrow your charger)

12. "tolong le ko taruhkan aku mulak" ( please take me home)

13. "oalang ko mendele mendengo karibu i" ( do not complain!) it will be good

14. "jaga ibe adek men" (please protection your younger brother)

From the data 10-14, it is seen that Pakpak people ask to other the speaker used 'ko' as personal subject pronouns by using Command as a signal of hearer.

15. "piga kalak ke sebeltek"(how many do you have brothers)

The example of data above use 'ke' it is more polite to ask other people older than speaker, used 'ke' as personal subject pronouns by using interrogative statement

\section{Why Pakpaknese Need To Show Personal Subject Pronouns}

From the previous explaination above, the researcher found why pakpak using personal subject pronouns in daily conversation.

16. "nggoh ko mangan mpung" (have you eaten, granma)

From the data 16 above it is found when speaker ask to other the speaker used Politeness as 'ko mangan mpung' it is meaning speak to older than speaker.

17. "jam piga ko laos sikolla dek" (what time do you go to school)

From the data represented above it is found when speaker speak to their people used Intimacy as 'ko laos sikolla dek' it is meaning speak to younger than speaker.

18. "kasa bagak ko" (why are you beautiful dek)

From the data 'kasa bagak ko' above, it is found when speaker speak to there people used Relationship other people. 
19. "nggoh ko mangan eda" "have you eaten eda"

From the example of data represented above, it is found when speaker speak to there people used Adapting situation.

\section{Findings}

Analysis data here was elaboration of test result in previous section and displayed the answer of three research problems, they were:

Table. 5 Result of Questions Types of Politeness personal subject pronouns by Pakpaknese

\begin{tabular}{|c|c|c|}
\hline Gender & Male & Female \\
\hline Male & Equal & Younger \\
\hline Female & Older & Younger \\
\hline
\end{tabular}

The Language by bahasa Pakpak conversation on daily conversation was anlyzed to answer the problem number one of types of politeness using personal subject pronouns. In speaking of $\mathrm{M} \rightarrow \mathrm{M}$, the equal or standard language were often used and in the speak $\mathrm{M} \leftrightarrow \mathrm{F}$, the younger language were often used. In speaking of $\mathrm{F} \rightarrow \mathrm{F}$, The younger language were often used and $\mathrm{F} \leftrightarrow \mathrm{M}$, the older language were often used.

Table 6. Result of Question How Do People in Jambu Mbellang District Show Pakpanese Personal Subject Pronouns Daily Conversation

\begin{tabular}{|l|l|}
\hline How do People Pakpaknese Show Personal Subject Pronouns. & \multicolumn{1}{c|}{ Data } \\
\hline Suggestion & 6 \\
\hline Offer & $10,11,12,13,14$ \\
\hline Command & $7,8,9$ \\
\hline Interrogative Stament & $1,2,3,4,5 \& 15$ \\
\hline
\end{tabular}

To show personal subject pronouns in the conversation of Pakpaknese to use theory sated by Brown and Levinson Namely: suggestion, offer, command and interrogative statement. Other such as suggestion rarely to be found in conversation.

Table 7. Result of Questions Why Pakpaknese Need To Show Personal Subject Pronouns

\begin{tabular}{|c|c|c|}
\hline Criteria Politeness & Meaning & Data \\
\hline Politeness & Sopan Santun & 16 \\
\hline Intimacy & Keakraban & 18 \\
\hline Relationship & Hubungan & 19 \\
\hline Adapting situation & Beradaptasi \\
\hline
\end{tabular}

When Pakpaknese show personal subject pronouns in daily conversation there are four category politeness by Mills (2003) it is politeness, intimacy, relationship and adapting situation. 


\section{DISCUSSION}

In Pragmatics study, Politeness has been widely conducted by some researcher. Politeness is important concept in society because it can controls people to do something through verbal it is language use or non-verbal it is the work/action. This study highlighted that Using Personal Subject Pronouns such Pakpaknese is really influenced the level of politeness, also help people in communicating to each other through the right way of using it.

It can be seen from the result of research analyzing that each type of Pakpaknese Personal Subject Pronouns show in daily conversation. they are: In the speak of $M \rightarrow M$, the equal or standard language were often used and in the speak $\mathrm{M} \leftrightarrow \mathrm{F}$, the younger language were often used. In the speak of $\mathrm{F} \rightarrow \mathrm{F}$, The younger language were often used and $\mathrm{F} \leftrightarrow \mathrm{M}$, the older language were often used. Second it is found people show politeness in Personal Subject Pronouns realized. when they are communication to each other and asking to someone there was found four speech function in conversation namely suggestion, command, offer, statement. Third why pakpaknese in jambu mbellang need to show personal subject pronouns researcher found intimacy, politeness, relation, adapting situation into ever conversation in Pakpak.

\section{CONCLUSION}

Based on the findings and discussion, the result of the research can be summarized as follows.In the application to show PakpaknesePersonal Subject Pronouns, people in Jambu Mbellang District mostly show: if speaker male speak male with criteria equal, and speaker male speak female with criteria younger while speaker female speak female it is found younger and speaker female speak male it is found older. The way of people Jambu Mbellang show Pakpaknese personal subject pronouns distinguish by suggestion, offer, command, interrogative statement. The reason of people show Pakpaknese personal subject pronouns were making adapting situations, intimacy, relationship and politeness.

\section{REFERENCES}

Arapah, E. 2017. Politeness in Using Banjarese and American English Personal Subject Pronouns by English Department Students of Lambung Mangkurat University. Journal of Language Teaching and Research 8.2 (2017)

Batak,Hita.2017.PersebaranSukudiSumateraUtara,6SukuBatak. www.hitabatak.com/persebaran-suku-di-sumatera-utara-6-suku-batak.

Brown, Penelope. 2015. Politeness and Language. Second edition. International Encyclopedia of the Social \& Behavioral Sciences. Netherlands: Max Planck Institute of Psycholinguistics.

Jumanto.Theory muka dan Kesantunan. Fakultas Bahasa Dan Budaya Universitas Semarang.

Rambe, J. (2016). Analysis Politeness In Batak Mandailing Movie. Jakarta: Universitas Katolik Indonesia Atma Jaya.

Richard J,Watts.(2003). Politeness. United States of America: Cambridge University Press

Yule, G. (2005). The Study of Language. Third Edition. United States of America: Cambridge University Press, New York. 